\title{
Kwalifikowanie technologii spawania prętów do zbrojenia betonu
}

\section{Rainforced concentrate bars welding technology qualifying}

\section{Streszczenie}

W artykule przedstawiono kryterium podziału prętów do zbrojenia betonu oraz klasy i gatunki prętów zbrojeniowych, omówiono zagadnienia związane z technologią wytwarzania oraz ich spawalnością. W części badawczej opisano procedurę kwalifikowania technologii spawania prętów na podstawie aktualnych norm.
Abstract

The article presents the criterion for the allocation of reinforced concrete bars, classes and grades of reinforcing bars, discusses issues related to manufacturing technology and their weldability. The research part describes the procedure for qualifying of welding of reinforced concentrate bars based on current standards.

\section{Wstęp}

Do kwalifikowania technologii spawania prętów żebrowanych do zbrojenia betonu wykorzystuje się badania nieniszczące i niszczące, takie jak: badania wizualne, makroskopowe, penetracyjne, badania na rozciąganie oraz twardości. Nie ma jednej normy, która w pełni opisywałaby proces kwalifikowania technologii spawania prętów żebrowanych. Procedura kwalifikowania opisana jest w dwóch odrębnych normach: EN ISO 17660-1:2008 Spawanie - Spawanie/zgrzewanie stali zbrojeniowej - Część 1: Złącza spawane/zgrzewane nośne oraz normę EN ISO 15614-1: 2008 Specyfikacja i kwalifikowanie technologii spawania metali - Badania technologii spawania - Część 1: Spawanie łukowe i gazowe stali oraz spawanie łukowe niklu i stopów niklu. Trzeba jednak zaznaczyć, że każda z tych norm opisuje tylko część zaleceń. Bazowanie na jednej z nich nie zapewnia pełnego kwalifikowania technologii spawania prętów żebrowanych.

Norma EN ISO 17660-1:2008 zawiera zalecenia dotyczące badań na rozciąganie i zginanie, a EN ISO 15614-1:2008 - badań wizualnych, badań penetracyjnych, badaniu twardości. Opracowanie jednej kompletnej normy, która opisywałaby proces kwalifikowania spawania prętów żebrowanych, byłoby ułatwieniem omawianej procedury.

Dr inż. Ryszard Pakos - Zachodniopomorski Uniwersytet Technologiczny w Szczecinie.
Pręty zbrojeniowe używane są w konstrukcjach żelbetowych, tj. konstrukcjach $z$ betonu i ułożonych w nim prętów ze stali zbrojeniowej. llość stali w konstrukcjach żelbetowych jest niewielka i na ogół nie przekracza $5 \%$ ich całkowitej objętości, jednak wprowadzenie prętów stalowych do konstrukcji betonowej umożliwia osiąganie bardziej wytrzymałych konstrukcji o większych wymiarach. Zadaniem prętów zbrojeniowych nośnych, rozdzielczych, strzemion oraz siatek stosowanych do konstrukcji betonowych jest ich wspólne przenoszenie sił, głównie rozciągających i poprzecznych, występujących podczas pracy konstrukcji. Wytrzymałość betonu na rozciąganie jest bardzo mała, zatem można przyjmować, że obciążenie rozciągające w konstrukcjach żelbetowych jest przenoszone tylko przez pręty zbrojeniowe. Zbrojenie stosowane jest również $w$ przypadku występowania dużych naprężeń ściskających i ograniczonych wymiarów przekroju betonu. Wówczas mogą występować niekorzystne dla konstrukcji żelbetowych zbyt duże naprężenia wywołane skurczem betonu i zmianami temperatury.

\section{Klasy i gatunki}

Zgodnie z PN-89/H-84023/06 stale do zbrojenia betonu dzieli się na 5 klas. Pręty zbrojeniowe, w zależności od klasy, rozróżnia się pod względem układu i nachylenia żeber na pobocznicy pręta. $\mathrm{Na}$ rysunku 1 przedstawiono pręty do zbrojenia 
betonu oraz ich układy użebrowania, natomiast na rysunku 2 pokazano klasy stali i przyporządkowane im gatunki wg PN-B-03264, oraz dodatkowe dwa gatunki nieujęte w normie - RB500W i BST500S (w ramach klasy AIIIN).

W klasie A-0 produkowane są pręty okrągłe gładkie ze stali St0S. W klasie A-I — pręty okrągłe gładkie o innych właściwościach mechanicznych i technologicznych zaliczane do gatunków St3SX i St3SY. Pręty zbrojeniowe w klasie A-II mają na powierzchni ukształtowane dwa żebra podłużne, biegnące równolegle do długości pręta. Pręty w klasie A-III są również żebrowane, podobnie jak w klasie A-II, z tym że żebra poprzeczne usytuowane są w tzw. „jodełkę" i nachylone do żeber podłużnych z jednej strony pręta pod kątem ok. $60^{\circ}$, a $z$ drugiej strony pod kątem $300^{\circ}$. Pręty 20G2VY produkowane w klasie A-IIIN, dla odróżnienia ich od prętów 34GS, mają nawalcowane dodatkowe odcinki żeber podłużnych między żeberami poprzecznymi.

W tablicy I przedstawiono gatunki i klasy stali do zbrojenia betonu wraz z ich podstawowymi właściwościami mechanicznymi oraz przydatnością do spajania, scharakteryzowaną maksymalną zawartością węgla i równoważnikiem węgla $\mathrm{C}_{\mathrm{e}}$.

W Polsce najczęściej używanymi gatunkami stali są: 18G2-b, 34GS, RB500, RB500W, BSt500S.
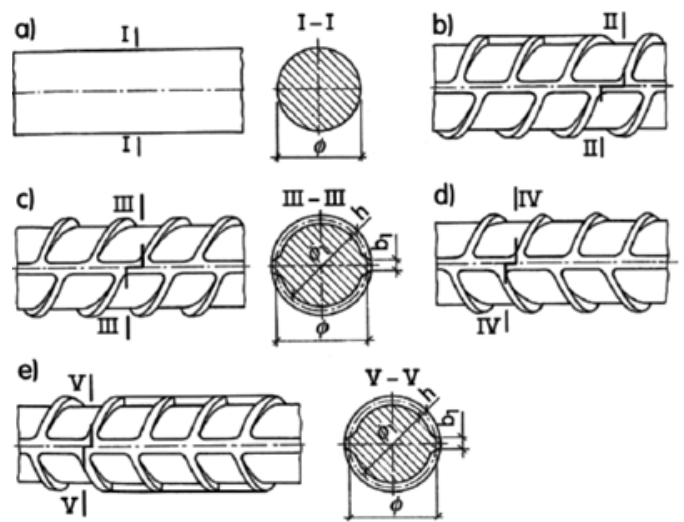

Rys. 1. Pręty zbrojeniowe ze stali: a) pręty gładkie (klasa A-0 i A-I), b) pręty żebrowane - dwa żebra jednoskośne (klasa A-II, stal St50b), c) pręty żebrowane (klasa A-II dla gatunku 18G2-b), d) pręty żebrowane - tzw. „dwa żeberka na jodełkę” (klasa A-III dla 34GS), e) pręty żebra (klasa A-IIIN dla gatunku 20G2VY-b) [7]

Fig. 1. Steel reinforced concentrate bar: a) plain bars (class $A-0$ and $A-I$ ), b) ribbed reinforcing bar - two skewed ribs (class A-II, grade St50b), c) ribbed reinforcing bar (Class A-II species 18G2-b), d) ribbed reinforcing bar (Class A-III to grade 34GS), e) ribbed reinforcing bar (class A-IIIN species 20G2VY-b) [7]

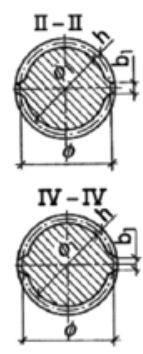

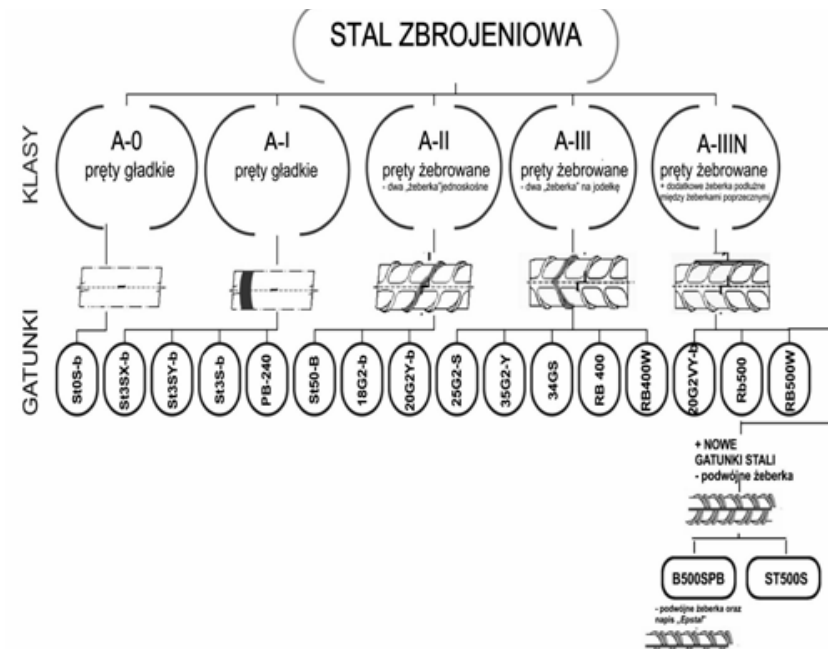

Rys. 2. Klasy i gatunki stali wg PN-B-03264 oraz dwa gatunki nieujęte w normie - RB500W i BST500S (klasa AIIIN) [7]

Fig. 2. Classes and grades acc. to PN-B-03264 and 2 not included in standard - RB500W and BST500S (class AIIIN) [7]

Tablica I. Charakterystyczne właściwości stali przeznaczonej na pręty zbrojeniowe [6]

Table I. Typical properties of steel for reinforced concentrate bar [6]

\begin{tabular}{|c|c|c|c|c|c|c|c|c|c|}
\hline \multirow{2}{*}{ Norma } & \multirow{2}{*}{$\begin{array}{l}\text { Gatunek } \\
\text { stali }\end{array}$} & \multirow{2}{*}{$\begin{array}{l}\text { Klasa } \\
\text { stali }\end{array}$} & \multirow{2}{*}{$\begin{array}{c}\text { Zakres } \\
\text { średnic, mm }\end{array}$} & \multirow{2}{*}{$\begin{array}{l}\mathrm{C}_{\max } \\
\%\end{array}$} & \multirow{2}{*}{$\mathrm{C}_{\mathrm{e}}$} & \multicolumn{4}{|c|}{ Wymagane właściwości mechaniczne prętów } \\
\hline & & & & & & $\mathrm{R}_{\mathrm{e}}$ lub $\mathrm{R}_{0.2} \min , \mathrm{MPa}$ & $\mathrm{R}_{\mathrm{m}}, \mathrm{MPa}$ & $A_{5} \min , \%$ & Kąt gięcia/średnica trzpienia gnącego \\
\hline \multirow{9}{*}{ 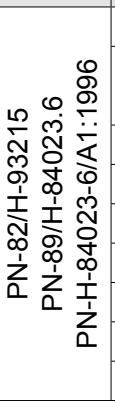 } & St-0b & $\mathrm{A}-\mathrm{O}$ & \multirow[b]{2}{*}{$5.5 \div 40$} & 0,23 & - & 220 & $310 \div 550$ & 22 & $180^{\circ} / 2 \mathrm{~d}$ \\
\hline & $\begin{array}{l}\text { St3Sx-b } \\
\text { St3Sy-b }\end{array}$ & A-I & & 0,22 & - & 240 & $370 \div 460$ & 24 & $180^{\circ} / 2 \mathrm{~d}$ \\
\hline & St50B & \multirow{3}{*}{ A-II } & \multirow[t]{2}{*}{$6 \div 32$} & 0,40 & - & \multirow{3}{*}{355} & $\min .490$ & 17 & $180^{\circ} / 3 \mathrm{~d}$ \\
\hline & 18G2-b & & & 0,22 & 0,48 & & \multirow{2}{*}{$490 \div 620$} & \multirow{2}{*}{20} & $180^{\circ} / 3 \mathrm{~d}$ \\
\hline & 20G2Y-b & & $6 \div 28$ & 0,23 & 0,48 & & & & $180^{\circ} / 2 \mathrm{~d}$ \\
\hline & $25 G 2 S$ & \multirow{3}{*}{ A-III } & $6 \div 40$ & 0,29 & 0,58 & 395 & \multirow{3}{*}{$\min .590$} & 14 & $90 \% / 3 \mathrm{~d}$ \\
\hline & $35 G 2 Y$ & & $6 \div 20$ & 0,35 & 0,59 & 410 & & \multirow{2}{*}{16} & $90^{\circ} / 3 \mathrm{~d}$ \\
\hline & $34 G S$ & & $6 \div 32$ & 0,36 & 0,59 & 410 & & & $90^{\circ} / 3 \mathrm{~d}$ \\
\hline & 20G2VY & A-IIIN & $6 \div 28$ & 0,23 & 0,52 & 490 & $590 \div 780$ & 13 & $90^{\circ} / 4 \mathrm{~d}$ \\
\hline \multirow{3}{*}{ 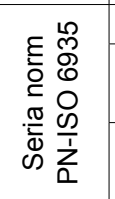 } & RB300 & \multirow{7}{*}{ A-IIIN } & \multirow{3}{*}{$6 \div 40$} & brak & brak & 300 & $\min .330$ & 16 & $160^{\circ} / 2 \div 4 \mathrm{~d}$ \\
\hline & $\begin{array}{c}\text { RB400 } \\
\text { RB400W }\end{array}$ & & & 0,22 & 0,50 & 400 & $\min .440$ & 14 & $160^{\circ} / 2.5 \div 5 \mathrm{~d}$ \\
\hline & $\begin{array}{c}\text { RB500 } \\
\text { RB500W }\end{array}$ & & & 0,24 & 0,52 & 500 & $\min .550$ & 14 & $160^{\circ} / 3 \div 6 \mathrm{~d}$ \\
\hline \multirow{2}{*}{ Z $\underset{\infty}{\infty}$} & BSt420S & & \multirow{2}{*}{$\begin{array}{c}6 \div 28 \\
(32)\end{array}$} & 0,22 & - & 420 & $\min .500$ & 10 & $180^{\circ} / 5 \div 8 \mathrm{~d}$ \\
\hline & BSt500S & & & 0,22 & - & 500 & $\min .550$ & 10 & $180^{\circ} / 5 \div 8 \mathrm{~d}$ \\
\hline \multirow{2}{*}{ 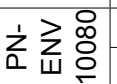 } & B500A & & $6 \div 16$ & 0,24 & 0,52 & 500 & $\min .1,05 x \operatorname{Re}$ & 2.5 & $90^{\circ} / 5 \div 10 \mathrm{~d}$ \\
\hline & B500B & & $6 \div 40$ & 0,24 & 0,52 & 500 & $\min .1,08 x \operatorname{Re}$ & 5 & $90^{\circ} / 5 \div 10 \mathrm{~d}$ \\
\hline
\end{tabular}




\section{Metody wytwarzania}

Stal zbrojeniowa wytwarzana jest przez huty i zakłady przetwórstwa hutniczego w postaci prętów gładkich i żebrowanych, walcówki i drutu w kręgach z powierzchnią gładką lub żebrowaną oraz jako siatki zgrzewane maszynowo z prętów lub z odcinków drutów.

Postęp w technologii wytwarzania wyrobów stalowych do zbrojenia betonu był ukierunkowany w minionych kilkunastu latach na uzyskanie zwiększonej wytrzymałości i granicy plastyczności, przy jednocześnie dobrej plastyczności i spajalności. Rozwój technologii walcowania i przetwórstwa hutniczego pozwala obecnie na uzyskanie żądanego kształtu i wymiarów wyrobów hutniczych z dużą dokładnością wymiarową.

Tradycyjna technologia wytwarzania prętów lub walcówki do zbrojenia betonu polega na walcowaniu na gorąco i naturalnym chłodzeniu w powietrzu po walcowaniu. Uzyskanie wysokiej granicy plastyczności prętów możliwe jest w wyniku zastosowania jednej z następujących technologii:

- obróbki cieplnej bezpośrednio po walcowaniu (przyspieszone chłodzenie), realizowanej z zastosowaniem jednej $z$ następujących odmian umacniania cieplnego: TEMPCORE, QTB;

- walcowania z regulowaną temperaturą prętów ze stali mikrostopowych, np. z mikrododatkiem wanadu i niobu;

- umacniania na zimno prętów przez skręcanie, rozciąganie i/lub nagniatanie użebrowania.

Najczęściej stosowane są technologie TEMPCORE i QTB.

W technologii TEMPCORE, która obejmuje obróbkę cieplną z wykorzystaniem ciepła walcowania, podwyższenie właściwości mechanicznych prętów uzyskuje się w wyniku zahartowania i samoodpuszczenia zewnętrznej warstwy pręta przechodzącego po zakończeniu walcowania przez linię intensywnego chłodzenia wodnego oraz w wyniku rozdrobnienia struktury ferrytyczno-perlitycznej w środkowej strefie pręta. Skład chemiczny stali na pręty żebrowane do zbrojenia betonu podany w normie PN-ISO 6935-2 określa dopuszczalne zawartości pierwiastków podstawowych (C, Mn, Si), resztkowych ( $\mathrm{Cr}, \mathrm{V}, \mathrm{Mo}, \mathrm{Cu}, \mathrm{Ni}, \mathrm{Sb}, \mathrm{Sn}$ ), domieszek szkodliwych (S, P), gazów $\left(\mathrm{N}_{2}, \mathrm{H}_{2}, \mathrm{O}_{2}\right)$ oraz maksymalną wartość równoważnika węgla $\mathrm{C}_{\mathrm{e}}$. Skład chemiczny stali wytwarzanych w kraju metoda umocnienia cieplnego, wg PN-ISO 6935-2:1998 oraz wg projektu PN-EN 10080:2007, podano w tablicy II.

Zastosowanie technologii TEMPCORE przynosi znaczne efekty:

- ekonomiczne (obniżenie kosztów produkcji prętów),

- technologiczne (produkcja wysokiej jakości prętów ze stali o $R_{e \min }-500 \mathrm{MPa}, A 5=15 \%$ oraz o bardzo dobrej spawalności i zgrzewalności),

- konstrukcyjne (znaczne zmniejszenie liczby i masy prętów stosowanych w konstrukcjach żelbetowych),

- jakościowe (polepszenie jakości powierzchni prętów przez zmniejszenie grubości zgorzeliny, zmniejszenie braków na skutek uszkodzenia powierzchni prętów, zapewnienie większej prostości prętów),

- organizacyjne (zmuszenie producentów prętów do przestrzegania ostrych wymagań narzuconych przez systemy jakości),

- rynkowe (eliminacja z rynku produkcji prętów o ograniczonej spawalności i zgrzewalności).

Technologia QTB (Quenching and Tempering Bars) opracowana przez firmę DANIELI jest odpowiednikiem metody kontrolowanego chłodzenia TEMPCORE. Zapewnia ona uzyskanie podwyższonych właściwości wytrzymałościowych prętów ze stali niskowęglowych przez zastosowanie w linii walcowania na gorąco odpowiedniego systemu trójfazowego kontrolowanego chłodzenia prętów.

Pod względem struktury wewnętrznej pręt poddany takiej obróbce cieplnej wykazuje przypowierzchniową warstwę martenzytu odpuszczonego, podczas gdy rdzeń pręta składa się z ferrytu i perlitu oraz struktur pośrednich.

Dzięki zastosowaniu technologii QTB uzyskuje się poprawę parametrów technicznych prętów:

- wysoką wytrzymałość na rozciąganie,

- dobrą spawalność dzięki możliwości zmniejszania zawartości węgla przy zachowaniu wysokiej umownej granicy plastyczności,

- dobrą zginalność bez występowania mikropęknięć na powierzchni pręta,

- bardzo dobrą charakterystykę zachowania się prętów w warunkach zmęczeniowych, osiąganą dzięki wysokiej plastyczności powierzchniowej warstwy martenzytu, co pozwala na wykorzystywanie prętów z QTB w elementach konstrukcyjnych poddawanych obciążeniom dynamicznym,

Tablica II. Wymagany skład chemiczny stali na pręty żebrowane wg PN-ISO 6935-2:1998 i PN-EN 10080:2007

Table II. Required chemical composition of steel for reinforced concentrate bar acc. to PN-ISO 6935-2:1998 and PN-EN 10080:2007

\begin{tabular}{|c|c|c|c|c|c|c|c|c|}
\hline \multirow{2}{*}{ Numer normy } & \multirow{2}{*}{ Gatunek stali } & \multicolumn{7}{|c|}{ Maksymalna zawartość pierwiastka, \% masy } \\
\hline & & C & $\mathrm{Mn}$ & $\mathrm{Si}$ & $\mathrm{P}$ & $S$ & $\mathrm{~N}$ & $\mathrm{C}_{\mathrm{e}}$ \\
\hline \multirow{2}{*}{ PN-ISO 6935-2 } & $\begin{array}{l}\text { RB300, RB400 } \\
\text { RB500 }\end{array}$ & - & - & - & $\begin{array}{c}0,060 \\
(0,050)^{1)}\end{array}$ & $\begin{array}{c}0,060 \\
(0,050)^{1)}\end{array}$ & - & - \\
\hline & $\begin{array}{l}\text { RB400W, } \\
\text { RB500W }\end{array}$ & 0,22 & 1,60 & 0,60 & 0,050 & 0,050 & 0,012 & $\begin{array}{c}0,50 \\
(0,55)^{2}\end{array}$ \\
\hline PN-EN 10080:2007 & B500A, B500B & 0,24 & - & - & 0,055 & 0,055 & 0,013 & 0,52 \\
\hline
\end{tabular}




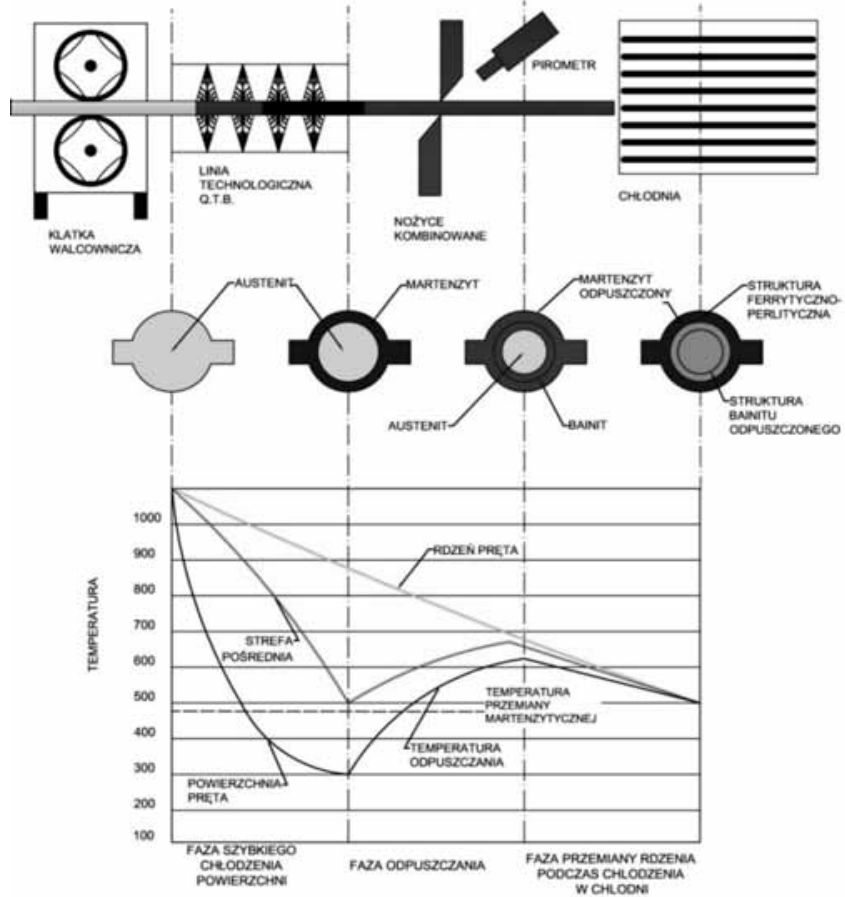

Rys. 3. Schemat przebiegu procesu technologii QTB [14]

Fig. 3. Scheme of QTB process [14]

- dzięki wysokiej stabilności cieplnej struktury poddanej obróbce cieplnej charakterystyka zachowania się prętów z QTB podczas pożaru nie odbiega od właściwości prętów walcowanych metodą klasyczną.

$\mathrm{Na}$ rysunku 3 przedstawiono uproszczony schemat procesu technologii QTB wraz z wykresem temperatura - fazy chłodzenia pręta żebrowanego.

\section{Spawalność}

Na spawalność stali prętów żebrowanych decydujący wpływ ma skład chemiczny (wyrażony wartością równoważnika węgla $\mathrm{C}_{\mathrm{e}}$ ), obecność wodoru dyfundują- cego oraz średnica pręta. Norma budowlana B-03264 oraz normy przedmiotowe na wytwarzanie spawalnych prętów ograniczają wartość równoważnika $\mathrm{C}_{\mathrm{e}}$ do $0,50 \%$. Wzrost grubości prętów zwiększa ryzyko podhartowań w strefie wpływu ciepła (SWC), co w obecności naprężeń spawalniczych oraz naprężeń pochodzących od obciążeń zewnętrznych może spowodować pęknięcie zimne.

W przypadku nowoczesnych prętów żebrowanych nie występuje ryzyko pękania gorącego, nagłego czy lamelarnego. Pęknięcia kruche ze względu na korzystną strukturę materiału pręta (obecność odpuszczonego martenzytu o niskiej twardości) nie powinny stanowić zagrożenia.

Przydatność stali zbrojeniowej do łączenia za pomocą spawania łukowego lub zgrzewania oporowego podano w tablicy III. Spawalność „zadowalająca” oznacza możliwość połączenia prętów przy zachowaniu odpowiednich warunków wykonania oraz przeprowadzenia badań wstępnych, natomiast spawalność „niedostateczna" lub (utrudniona) oznacza, że stal, z uwagi na skład chemiczny, stwarza trudności w połączeniu metodami spawania i zgrzewania, jednak nie uniemożliwia połączenia prętów innymi metodami.

\section{Rodzaje połączeń spawanych}

Połączenia spawane prętów zbrojeniowych można podzielić na złącza spawane nośne i złącza spawane nienośne (rys. 4). Złącza nośne są to złącza spawane stosowane do przenoszenia specyficznych obciążeń ze stali zbrojeniowej. Złącza spawane nienośne są to złącza, których wytrzymałość jest nieuwzględniana przy projektowaniu konstrukcji do zbrojenia betonu. Zadaniem nieobciążonego złącza spawanego jest zwykle zapewnienie wzajemnego położenia elementów do zbrojenia betonu podczas produkcji, transportu i betonowania. Stosowane połączenia spawanych prętów zbrojeniowych można podzielić

Tablica III. Ogólna charakterystyka spawalności krajowych stali zbrojeniowych [10] Table. III. Typical weldability of domestic steels for reinforced concentrate bars [10]

\begin{tabular}{|c|c|c|c|c|}
\hline \multirow{3}{*}{$\begin{array}{c}\text { Klasa } \\
\text { stali }\end{array}$} & \multirow{3}{*}{ Gatunek stali } & \multicolumn{3}{|c|}{ Spawalność lub zgrzewalność stali zbrojeniowej przy zastosowaniu } \\
\hline & & \multirow{2}{*}{ spawania łukowego } & \multicolumn{2}{|l|}{ zgrzewania oporowego } \\
\hline & & & doczołowego & punktowego \\
\hline $\mathrm{A}-0$ & St0S-b & dobra (do $d=25 \mathrm{~mm}$ ) & dobra & \\
\hline \multirow{3}{*}{$A-I$} & St3SX-b & dobra (do $\mathrm{d}=25 \mathrm{~mm}$ ) & dobra & \\
\hline & St3SY-b & dobra & dobra & \\
\hline & PB 240 & \multirow{2}{*}{ utrudniona } & \multicolumn{2}{|l|}{ brak danych } \\
\hline \multirow{3}{*}{ A-II } & St50B & & dobra (wymaga przeprowadzania wstępnych prób zgrzewalności) & niedostateczna \\
\hline & 18G2-b & dobra & \multicolumn{2}{|l|}{ dobra } \\
\hline & $20 G 2 Y-b$ & zadowalająca & \multicolumn{2}{|l|}{ zadowalająca } \\
\hline \multirow{7}{*}{ A-III } & $25 \mathrm{G} 2 \mathrm{~S}$ & \multirow{4}{*}{ utrudniona } & \multicolumn{2}{|l|}{ zadowalająca } \\
\hline & $25 G 2 Y$ & & \multicolumn{2}{|l|}{ zadowalająca } \\
\hline & $34 G S$ & & \multicolumn{2}{|l|}{ dobra (zgrzewanie prętów prostych) } \\
\hline & RB 400 & & \multicolumn{2}{|l|}{ brak danych } \\
\hline & RB400 W & bardzo dobra & \multicolumn{2}{|l|}{ bardzo dobra } \\
\hline & RB 500 & utrudniona & \multicolumn{2}{|l|}{ brak danych } \\
\hline & RB 500W & bardzo dobra & \multicolumn{2}{|l|}{ bardzo dobra } \\
\hline
\end{tabular}




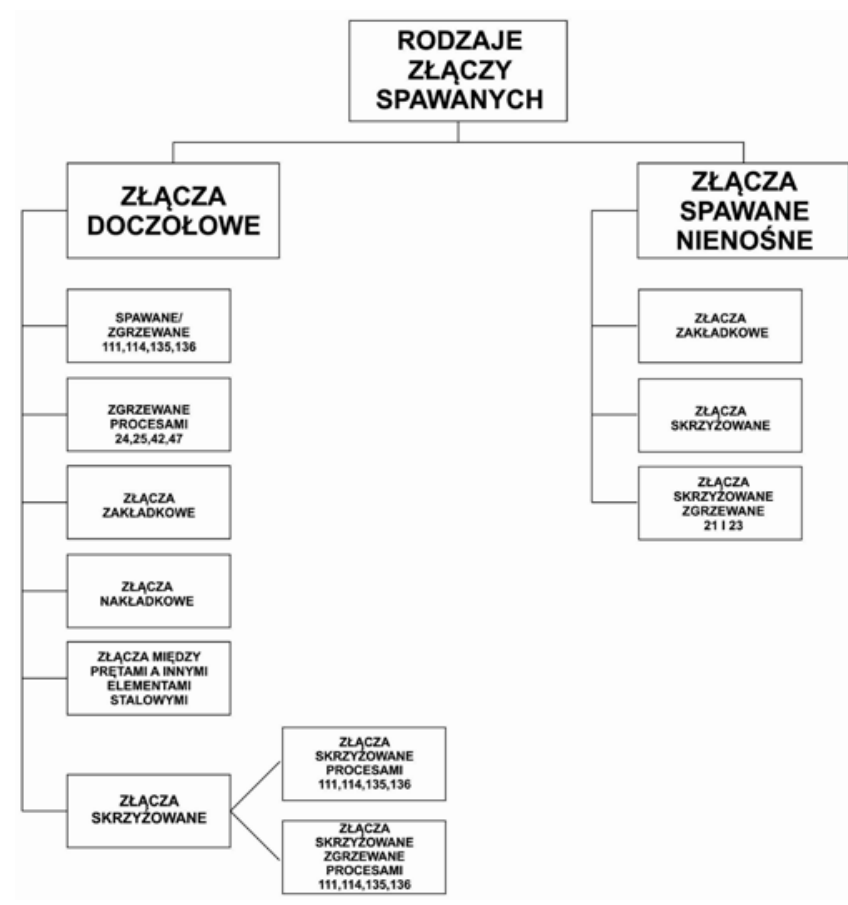

Rys. 4. Klasyfikacja złączy spawanych wg rodzaju

Fig. 4. Welded joint type classification

na następujące rodzaje złączy: doczołowe, zakładkowe, nakładkowe, krzyżowe, złącza z innym elementem stalowym, złącza inne.

\section{Metody spawania}

Norma EN ISO 17660:2008 Spawanie - Spawanie/ zgrzewanie stali zbrojeniowej podaje zalecane średnice prętów do zbrojenia betonu dla różnych rodzajów istopniodpowiedzialności złączy spajanych stosowanych w praktyce budowlanej. W tablicy IV przedstawiono zalecane metody spajania prętów do zbrojenia betonu.

W teorii pręty zbrojeniowe można łączyć kilkoma metodami spawania (procesy 111, 135, $136 \mathrm{wg}$ PN-EN ISO 4063), ale praktycznie metodą najczęściej stosowaną przez wykonawców jest metoda ręcznego spawania elektrodą otuloną (111), która w warunkach zarówno warsztatowych, jak i na placu budowy ma sporo zalet w porównaniu z pozostałymi, tj. łatwość transportu źródeł inwertorowych do kolejnych stanowisk w czasie pracy, wyeliminowanie butli gazowych, większą odporność na podmuchy wiatru oraz mniejszą awaryjność od bardziej skomplikowanych półautomatów spawalniczych MIG/MAG.

\section{Badania złączy próbnych i kryteria oceny}

Złącza próbne określa się na podstawie analizy projektu konstrukcyjnego obiektu, dla którego będzie wykonywane uznanie/kwalifikowanie technologii spawania. Analizie podlegają następujące elementy złączy nośnych: grupy (gatunki) stali spawanych elementów konstrukcji zbrojenia (pręty, blachy), średnica prętów, grubość blach, typy połączeń, rodzaj i grubość spoin.

$\mathrm{Na}$ podstawie tych danych należy wybrać złącza reprezentatywne dla występujących połączeń, grubości spoin i materiałów, uwzględniając zakres kwalifikowania. W praktyce projektanci dążą do unifikacji konstrukcji zbrojenia, co zmniejsza liczbę zmiennych parametrów, a w wielu przypadkach może nawet oznaczać jeden typ pręta nośnego (gatunek, średnica) z jednym typem połączenia.

Tablica IV. Zalecane metody spajania prętów do zbrojenia betonu [2]

Table IV. Recommended methods for rainforced concentrate bars welding [2]

\begin{tabular}{|c|c|c|c|}
\hline \multirow{2}{*}{$\begin{array}{l}\text { Numer metody spajania wg PN-EN ISO } 4063 \\
\text { (nazwa metody spajania) }\end{array}$} & \multirow{2}{*}{ Rodzaj złącza spajanego } & \multicolumn{2}{|c|}{ Zakres średnic prętów dla złączy, mm } \\
\hline & & nośnych"1) & nienośnych ${ }^{2)}$ \\
\hline 21 (zgrzewanie punktowe oporowe) & zakładkowe & nie ma zastosowania & $5 \div 50$ \\
\hline 23 (zgrzewanie garbowe) & krzyżowe & $5 \div 20$ & $5 \div 50$ \\
\hline $\begin{array}{l}24 \text { (zgrzewanie iskrowe), } \\
25 \text { (zgrzewanie zwarciowe) }\end{array}$ & doczołowe & $5 \div 50$ & nie ma zastosowania \\
\hline 42 (zgrzewanie tarciowe) & $\begin{array}{c}\text { doczołowe, } \\
\text { doczołowe } \mathrm{z} \text { inną stalą }\end{array}$ & $6 \div 50$ & nie ma zastosowania \\
\hline 47 (zgrzewanie gazowe; płomieniowe) & doczołowe & $6 \div 50$ & nie ma zastosowania \\
\hline \multirow{6}{*}{$\begin{array}{l}111 \text { (spawanie łukowe elektrodą otuloną) } \\
114 \text { (spawanie łukowe drutem proszkowym samoosłonowym) } \\
135 \text { (spawanie łukowe metodą MAG) } \\
136 \text { (spawanie łukowe drutem proszkowym w atmosferze } \\
\text { gazu aktywnego) }\end{array}$} & doczołowe bez podkładki & $\geq 16$ & nie ma zastosowania \\
\hline & doczołowe z podkładką & $\geq 12$ & nie ma zastosowania \\
\hline & zakładkowe & $6 \div 50$ & $6 \div 50$ \\
\hline & nakładkowe & $6 \div 50$ & nie ma zastosowania \\
\hline & krzyżowe & $6 \div 50$ & $6 \div 50$ \\
\hline & doczołowe $\mathrm{z}$ inną stalą & $6 \div 50$ & $6 \div 50$ \\
\hline \multicolumn{4}{|c|}{$\begin{array}{l}\text { 1) Złącza spajane wykonane z prętów do zbrojenia betonu, stosowane do przenoszenia głównych obciążeń przez pręty oraz elementy } \\
\text { stalowe połączone z prętami. } \\
\text { 2) Złącza spajane, których wytrzymałość nie jest brana pod uwagę w fazie projektowania konstrukcji zbrojeniowej; służą tylko do utrzymania } \\
\text { elementów zbrojenia we właściwej pozycji podczas wytwarzania, transportu i montażu konstrukcji. }\end{array}$} \\
\hline
\end{tabular}


Zakres badań złączy próbnych przedstawiono w tablicy V. Badania nieniszczące (NDT) zaleca się wykonać najwcześniej po upływie $24 \mathrm{~h}$ po zakończeniu spawania w celu ujawnienia ewentualnych pęknięć zimnych.

Badania niszczące wykonuje się na złączach, które uzyskały pozytywny wynik badań nieniszczących (NDT). W praktyce jest istotne, aby badania zostały wykonane przez akredytowane laboratorium, a badania nieniszczące przez certyfikowany personel.

W wyniku obserwacji złącza można określić charakter krystalizacji pierwotnej materiału spoiny, niezgodności spawalnicze wewnętrzne i zewnętrzne, jakość wtopienia metalu spoiny w materiał łączony, szerokość strefy wpływu ciepła oraz makrostrukturę materiału podstawowego.

W przypadku badań wykonywanych na złączach prętów zbrojeniowych zakres potrzebnych badań przedstawiono $w$ tablicy $\mathrm{V}$.

Liczba złączy próbnych jest pochodną zakresu badań, co oznacza, że dla technologii spawania prętów spoinami czołowymi potrzeba 8 złączy, a dla prętów ze spoinami pachwinowymi 4 złącza, z wyjątkiem złączy krzyżowych, które wymagają 7 próbek (próby twardości można wykonać na próbkach makroskopowych po wykonaniu fotografii).

Dla złączy ze spoinami czołowymi długość próbek do badań mechanicznych przyjmuje się rzędu $300 \mathrm{~mm}$. Dla złączy ze spoinami pachwinowymi długość próbek do próby rozciągania powinna być większa, rzędu $700 \div 800 \mathrm{~mm}$.
Do prób spawania prętów zbrojeniowych należy dobrać materiały dodatkowe, które:

- zapewniają stopiwo o granicy plastyczności $R_{\text {emin }}$ równej, a w praktyce bezpieczniej - o 10 $\div 15 \%$ wyższej od granicy plastyczności łączonych prętów. Jest to szczególnie ważne przy spawaniu prętów ze stali wysokowytrzymałej;

- mają dobre technologiczne właściwości spawalnicze, czyli charakteryzują się dobrym równomiernym stapianiem, zapewniają równomierne kształtowanie spoiny oraz małą ilość rozprysków;

- są uznane przez instytucje dozoru technicznego, np.: UDT, TÜV, DB lub morskie towarzystwa klasyfikacyjne;

- mają kartę katalogową z danymi technologicznymi oraz dokument kontroli wg normy EN 10204 - tzw. certyfikat wytwórcy;

- w przypadku elektrod otulonych, dodatkowo, są dostępne w opakowaniach próżniowych, co eliminuje problem z suszeniem, kłopotliwy na budowie.

\section{Badania własne złącza próbnego}

W celu zobrazowania procesu kwalifikowania prętów żebrowanych przedstawiono badanie złącza wykonanego na pręcie żebrowanym o średnicy $25 \mathrm{~mm}$. Pręty połączono w złączu zakładkowym jednostronną spoiną pachwinową w pozycji podolnej (PA)

Tablica V. Zakres badań złączy próbnych i dotyczące ich wymagania [3-5]

Table V. The range of tests for test-joint and requirement for it [3-5]

\begin{tabular}{|c|c|c|c|}
\hline Złącze próbne & Rodzaj badań & Zakres badań & Wymagania \\
\hline \multirow{7}{*}{$\begin{array}{l}\text { pręt + pręt } \\
\text { ze spoiną czołową }\end{array}$} & badania wizualne (VT) & $100 \%$ & B wg EN ISO 5817 \\
\hline & badania na pęknięcia powierzchniowe: PT/MT & $100 \%$ & B wg EN ISO 5817 \\
\hline & badania radiologiczne (RT) & $100 \%$ & B wg EN ISO 5817 \\
\hline & próba rozciągania & 3 próbki & zerwanie w materiale ${ }^{1)}$ \\
\hline & próba zginania & 4 próbki & kąt zginania $120^{\circ} 2$ \\
\hline & badania makroskopowe & 1 próbka & B wg EN ISO 5817 \\
\hline & próba twardości HV105) & 1 próbka & dopuszczalna maksymalna twardość 3 \\
\hline \multirow{5}{*}{$\begin{array}{l}\text { pręt + pręt } \\
\text { ze spoiną pachwinową* }\end{array}$} & badania wizualne (VT) & $100 \%$ & C wg EN ISO 58174) \\
\hline & badania na pęknięcia powierzchniowe: PT/MT & $100 \%$ & C wg EN ISO 5817 \\
\hline & próba rozciągania & 3 próbki & zerwanie w materiale ${ }^{1)}$ \\
\hline & badania makroskopowe & 2 próbki & C wg EN ISO 5817 \\
\hline & próba twardości HV 105) & 2 próbki & dopuszczalna maksymalna twardośćc) \\
\hline \multirow{4}{*}{$\begin{array}{l}\text { pręt + blacha, } \\
\text { spoina pachwinowa }\end{array}$} & badania wizualne (VT) & $100 \%$ & C wg EN ISO 5817 \\
\hline & badania na pęknięcia powierzchniowe: PT/MT & $100 \%$ & C wg EN ISO 5817 \\
\hline & badania makroskopowe & 2 próbki & C wg EN ISO 58174) \\
\hline & próba twardości HV 105) & 2 próbki & dopuszczalna maksymalna twardość ${ }^{3)}$ \\
\hline \multicolumn{4}{|c|}{$\begin{array}{l}\text { *) Dla złączy skrzyżowanych wymagana jest dodatkowo próba ścinania (3 próbki). } \\
\text { 1) W przypadku zerwania w spoinie: Rm > od minimalnej wartości wytrzymałości dla danej stali, dla spoin pachwinowych należy uwzględni } \\
\text { współczynnik ścinania. } \\
\text { 2) } 2 \text { próbki z rozciąganiem lica, } 2 \text { próbki z rozciąganiem grani. } \\
\text { 3) Dopuszczalna maksymalna twardość HV 10: } 350 \text { - dla stali grupy } 1 \text { i } 2 \text { wg ISO/TR 15608; } 420 \text { - dla stali grupy } 3 \text { wg ISO/TR } 15608 \text {. } \\
\text { 4) Próbki pobrać z obu końców spoiny. } \\
\text { 5) Próbę twardości wykonać na próbkach makroskopowych, po wykonaniu fotografii. }\end{array}$} \\
\hline
\end{tabular}




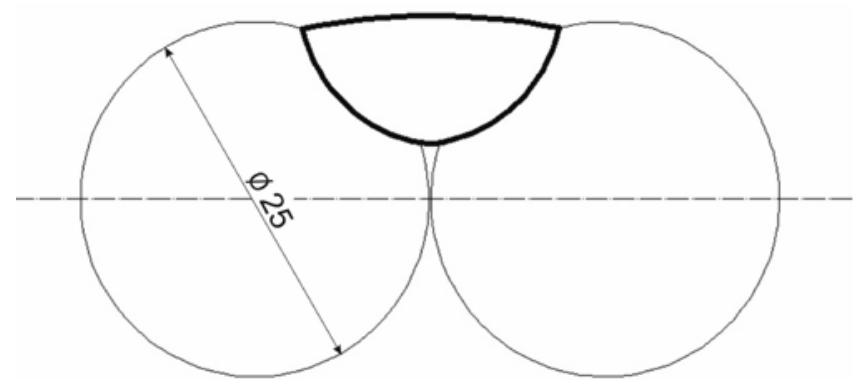

Rys. 5. Przekrój połączenia zakładkowego jednostronnego prętów wykonanego w pozycji podolnej (PA)

Fig. 5. Cross section of overlap joint of bars made in the flat welding position (PA)

- rysunek 5. Na podstawie EN ISO 17660-1:2008 oraz EN ISO 15614-1:2008 przeprowadzona została procedura kwalifikowania technologii spawania prętów żebrowanych do zbrojenia betonu.

\section{Charakterystyka badanego pręta}

W celu przeprowadzenia kwalifikowania technologii spawania prętów żebrowanych do zbrojenia betonu wykonano badania nieniszczące (NDT) i niszczące: wizualne (VT), penetracyjne (PT), wytrzymalości

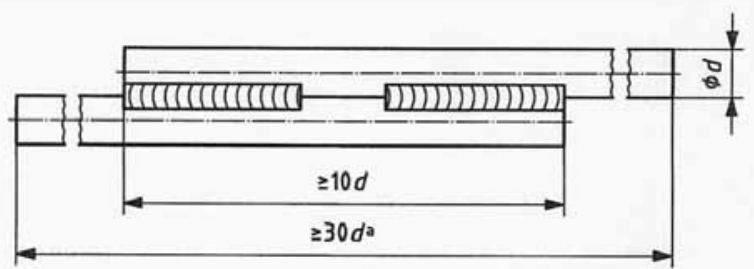

Rys. 6. Próbka do badania złącza zakładkowego (badanie na rozciąganie) zgodnie z PN EN-ISO 17660-1:2008

Fig. 6. Sample for testing with overlap joints (tensile test) acc. to EN ISO 17660-1:2008

Tablica VI. Charakterystyka badanego pręta

Table. VI. Characteristic of tested rainforced concentrate bar

\begin{tabular}{|c|c|c|c|c|c|c|}
\hline Pręt zbrojeniowy & Wyrób & Stan & Przeznaczenie & Gatunek & Norma & Wymiar, mm \\
\hline A & $\begin{array}{c}\text { pręt gorąco walcowany } \\
\text { okrągły żebrowany }\end{array}$ & surowy & do zbrojenia betonu & BSt500S & DIN488-1:84/DIN 488-2:86 & 25 \\
\hline
\end{tabular}

Tablica VII. Skład chemiczny oraz właściwości mechaniczne badanego pręta zbrojeniowego

Table VII. Chemical composition and mechanical boroperties of tested rainfroced concentrate bar

\begin{tabular}{|c|c|c|c|c|c|c|c|c|c|c|c|c|}
\hline \multirow{2}{*}{$\begin{array}{c}\text { Pręt } \\
\text { zbrojeniowy }\end{array}$} & \multicolumn{11}{|c|}{ Skład chemiczny wytopu, \% } & \multirow{2}{*}{ Równoważnik węgla $C_{e}$} \\
\hline & C & $\mathrm{Mn}$ & $\mathrm{Si}$ & $P$ & $\mathrm{~s}$ & $\mathrm{Ce}$ & $\mathrm{Ni}$ & $\mathrm{Cu}$ & Mo & $\mathrm{V}$ & $\mathrm{N}$ & \\
\hline \multirow{5}{*}{ A } & 0,21 & 0,9 & 0,14 & 0,014 & 0,035 & 0,09 & 0,09 & 0,3 & 0,02 & 0,002 & 0,009 & 0,41 \\
\hline & \multicolumn{12}{|c|}{ Równoważnik węgla $\mathrm{C}_{\mathrm{e}}$ wg wzoru $\mathrm{C}_{\mathrm{e}}=\mathrm{C}+\mathrm{Mn} / 6+(\mathrm{Cr}+\mathrm{Mo}+\mathrm{V}) / 5+(\mathrm{Ni}+\mathrm{Cu}) 15$} \\
\hline & \multicolumn{12}{|c|}{ Właściwości mechaniczne } \\
\hline & \multicolumn{4}{|c|}{$R_{m}, N / m^{2}$} & \multicolumn{3}{|c|}{$\mathrm{R}_{\mathrm{e}}, \mathrm{N} / \mathrm{mm}^{2}$} & \multicolumn{2}{|c|}{$\mathrm{R}_{\mathrm{m}} / \mathrm{R}_{\mathrm{e}}$} & \multicolumn{2}{|c|}{$\mathrm{A} 10, \%$} & Agt, \% \\
\hline & \multicolumn{4}{|c|}{680} & \multicolumn{2}{|c|}{573} & & 1,19 & & \multicolumn{2}{|c|}{18,2} & 10,5 \\
\hline
\end{tabular}

Tablica VIII. Metody spawania badanych prętów

Table. VIII. Welding mehods of tested rainforced concentrate bars

\begin{tabular}{|c|c|c|c|c|c|}
\hline $\begin{array}{c}\text { Pręt } \\
\text { zbrojeniowy }\end{array}$ & $\begin{array}{c}\text { Metoda spawania } \\
\text { PN-EN ISO 4063 }\end{array}$ & $\begin{array}{c}\text { Rodzaj wykonanej spoiny } \\
\text { PN-EN 287-1 }\end{array}$ & $\begin{array}{c}\text { Pozycja spawania } \\
\text { PN-EN ISO 6947 }\end{array}$ & $\begin{array}{c}\text { Rodzaj użytej } \\
\text { elektrody }\end{array}$ & $\begin{array}{c}\text { Klasa elektrody } \\
\text { Wg EN 757 }\end{array}$ \\
\hline A & 111 & FW & PF & OK. 74.78 & E 55 4 Mn Mo B 3 2 H5 \\
\hline
\end{tabular}

Tablica IX. Wyniki badania wizualnego złącza spawanego pręta zbrojeniowego o średnicy $25 \mathrm{~mm}$

Table. IX. Results of visual testing of welded joint of reinforced concentrate bar with diameter of $25 \mathrm{~mm}$

\begin{tabular}{|c|c|c|c|c|c|c|c|c|c|c|c|c|c|c|c|c|c|c|c|}
\hline \multirow{2}{*}{$\begin{array}{l}\text { Numer } \\
\text { próbki }\end{array}$} & \multirow{2}{*}{ Lico/grań } & \multicolumn{17}{|c|}{ PN-EN ISO 6520-1:2009 / PN-EN ISO 5817:2009 } & \multirow[b]{2}{*}{ Wynik } \\
\hline & & 101 & 102 & 103 & 104 & 402 & 504 & 507 & 508 & 509 & 510 & 512 & 514 & 515 & 5011 & 5012 & 5013 & INNE & \\
\hline A.1 & $\mathrm{L}$ & & & & & & & & & & & & B & & & & & & B \\
\hline A.2 & $\mathrm{L}$ & & & & & & & & & & & & & & & & & & $\mathrm{B}$ \\
\hline A.3 & L & & & & & & & & & & & & B & & & & & & $\mathrm{B}$ \\
\hline A.4 & $\mathrm{L}$ & & & & & & & & & & & & & & & & & & $\mathrm{B}$ \\
\hline
\end{tabular}

Tablica X. Wyniki badania na rozciąganie złącza zakładkowego pręta o średnicy $25 \mathrm{~mm}$

Table X. Results of tensile test of overlap joint of reinforced concentrate bars with diameter of $25 \mathrm{~mm}$

\begin{tabular}{|c|c|c|c|c|c|c|c|}
\hline Numer próbki & Średnica badanego pręta, $\mathrm{mm}$ & $\mathrm{R}_{\mathrm{m}}, \mathrm{MPa}$ & $\mathrm{A}_{\mathrm{n}}, \mathrm{mm}^{2}$ & $\mathrm{~A}_{\mathrm{n}} \times \mathrm{R}_{\mathrm{m}}, \mathrm{kN}$ & $\mathrm{F}_{\max }, \mathrm{kN}$ & Miejsce pęknięcia & Wynik \\
\hline A.1 & $\varnothing 25$ & 550,0 & 490,9 & 270,0 & 325,0 & $\mathrm{M}$ & pozytywny \\
\hline A.2 & $\varnothing 25$ & 550,0 & 490,9 & 270,0 & 325,5 & $\mathrm{M}$ & pozytywny \\
\hline A.3 & $\varnothing 25$ & 550,0 & 490,9 & 270,0 & 325,0 & $\mathrm{M}$ & pozytywny \\
\hline
\end{tabular}

gdzie: $A_{n}$ - nominalne pole przekroju poprzecznego pręta $w m^{2} ; F_{m a x}-$ maksymalna siła rozciągająca, $N ; R_{m}-$ nominalna wytrzymałość na rozciąganie pręta, $\mathrm{N} / \mathrm{mm}^{2}$ wg DIN 488-1 09/84; $\mathrm{M}$ - materiał; $\mathrm{S}$ - spoina 

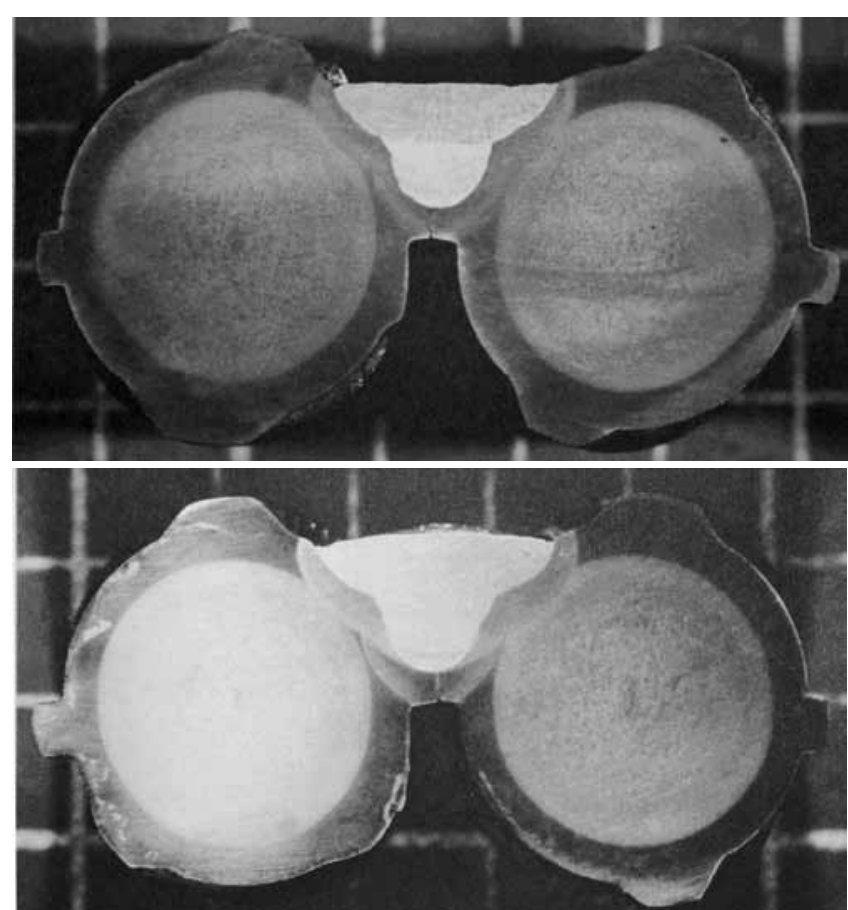

Rys. 7. Makrostruktura złącza zakładkowego pręta o średnicy $25 \mathrm{~mm}$ - próbki A. 1 i A. 2

Fig. 7. Macrostructure of overlap joint of reinforced concentrate bars with diameter of $25 \mathrm{~mm}$ - samples A.1 and A.2

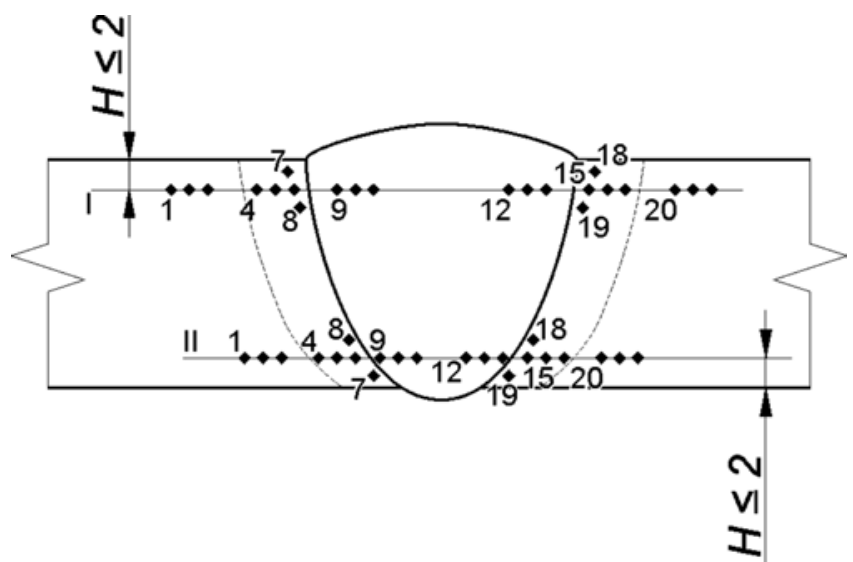

Rys. 8. Miejsca badania twardości na próbce A.1

Fig. 8. Hardness measurement points in sample A.1

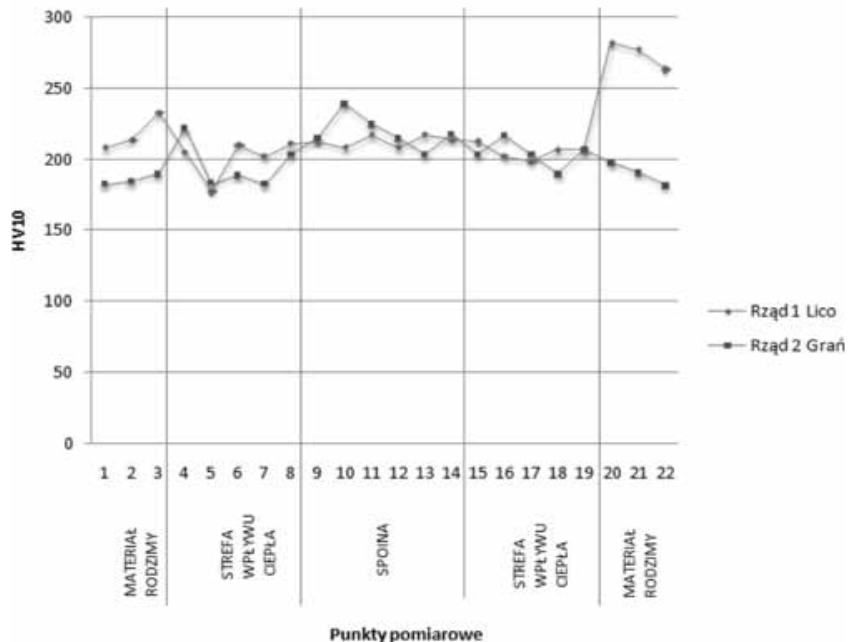

Rys. 9. Wykres rozkładu twardości w poszczególnych punktach pomiarowych

Fig. 9. Hardness distribution in measurements points
Tablica XI. Wyniki badania twardości dla próbki A.1

Table. XI. Sample A.1 hardness measurement results

\begin{tabular}{|c|c|c|c|c|c|}
\hline \multicolumn{3}{|c|}{ Rząd 1 lico } & \multicolumn{3}{|c|}{ Rząd 2 grań } \\
\hline $\begin{array}{c}\text { Punkt } \\
\text { pomiarowy }\end{array}$ & HV 10 & & $\begin{array}{c}\text { Punkt } \\
\text { pomiarowy }\end{array}$ & HV 10 & \\
\hline 1 & 208 & \multirow{3}{*}{$\begin{array}{l}\text { materiał } \\
\text { rodzimy }\end{array}$} & 1 & 183 & \multirow{3}{*}{$\begin{array}{l}\text { materiał } \\
\text { rodzimy }\end{array}$} \\
\hline 2 & 214 & & 2 & 185 & \\
\hline 3 & 233 & & 3 & 190 & \\
\hline 4 & 205 & \multirow{5}{*}{ SWC } & 4 & 222 & \multirow{5}{*}{ SWC } \\
\hline 5 & 178 & & 5 & 184 & \\
\hline 6 & 210 & & 6 & 189 & \\
\hline 7 & 202 & & 7 & 183 & \\
\hline 8 & 211 & & 8 & 204 & \\
\hline 9 & 213 & \multirow{6}{*}{ spoina } & 9 & 215 & \multirow{6}{*}{ spoina } \\
\hline 10 & 208 & & 10 & 239 & \\
\hline 11 & 217 & & 11 & 225 & \\
\hline 12 & 208 & & 12 & 215 & \\
\hline 13 & 217 & & 13 & 204 & \\
\hline 14 & 214 & & 14 & 218 & \\
\hline 15 & 213 & \multirow{5}{*}{ SWC } & 15 & 204 & \multirow{5}{*}{ SWC } \\
\hline 16 & 202 & & 16 & 217 & \\
\hline 17 & 199 & & 17 & 204 & \\
\hline 18 & 207 & & 18 & 190 & \\
\hline 19 & 207 & & 19 & 207 & \\
\hline 20 & 282 & \multirow{3}{*}{$\begin{array}{l}\text { materiał } \\
\text { rodzimy }\end{array}$} & 20 & 198 & \multirow{3}{*}{$\begin{array}{l}\text { material } \\
\text { rodzimy }\end{array}$} \\
\hline 21 & 277 & & 21 & 191 & \\
\hline 22 & 264 & & 22 & 182 & \\
\hline
\end{tabular}

na rozciąganie, twardości i makroskopowe. Badania wykonano zgodnie $\mathrm{z}$ zaleceniami zawartymi w normach:

- EN ISO 17660-1 - Spawanie/zgrzewanie stali zbrojeniowej - Część 1: Złącza spawane/zgrzewane nośne,

- EN ISO 15614-1 - Specyfikacja i kwalifikowanie technologii spawania metali - Badanie technologii spawania - Część 1: Spawanie łukowe i gazowe stali oraz spawanie łukowe niklu i stopów niklu.

\section{Wyniki badań wg EN ISO 17660-1 i EN ISO15614-1}

Zgodnie z wytycznymi norm badania laboratoryjne rozpoczęto po upływie $24 \mathrm{~h}$ od zakończenia spawania.

Po przeprowadzeniu badania wizualnego zgodnie $z$ wytycznymi PN-EN 17637 stwierdzono (tabl. IX), że złącze wykonane $z$ pręta o średnicy $25 \mathrm{~mm}$ spełnia wymagania jakościowe, a uzyskany poziom akceptacji określono jako wysoki (B) wg PN-EN ISO 5817:2009. Niezgodności określono zgodnie z PN-EN 6520. Jedyną znalezioną niezgodnością była nierówność lica, która ma niewielki wpływ na jakość i poprawność złącza. 
Badania penetracyjne nie wykazały niezgodności na badanych próbkach. Poziom akceptacji zgodnie z PN-EN ISO 23277:2010 został określony na poziomie 1.

Badanie wytrzymałości na rozciąganie zostało wykonane zgodnie $z$ wymaganiami zawartymi w normie, nie było potrzeby badania dwóch dodatkowych próbek. Wszystkie próby uzyskały wynik pozytywny (tabl. X), co oznacza, że spełniony został warunek przedstawiony w normie, mówiący, że wartość maksymalnej siły rozciągającej dla badanych próbek ma być wyższa od iloczynu nominalnego przekroju poprzecznego pręta oraz nominalnej wytrzymałości pręta na rozciąganie, tj. $550 \mathrm{MPa}$. W każdej z próbek miejscem pęknięcia nie była spoina, lecz materiał rodzimy, co oznacza, że wytrzymałość spoiny była większa od wytrzymałości materiału rodzimego.

Badanie makroskopowe zostało wykonane zgodnie z warunkami określonymi w normie. Na próbkach A.1 i A.2, widocznych na rysunku 6 , nie znaleziono niezgodności w postaci: pęknięcia, porowatości, a regularny kształt każdej powierzchni próbki świadczy o poprawnie wykonanym złączu. Na każdej z próbek widać linię wtopienia między materiałem dodatkowym a materiałem rodzimym, wtopienie ma regularny i prawidłowy kształt. Spoina ma wyraźne, równomierne wtopienie oraz wyraźne, równomierne ściegi. Strefa wpływu ciepła (SWC) również jest równomierna.

Badanie twardości wykonano zgodnie z wymaganiami zawartymi w normie. Wszystkie próby uzyskały wynik pozytywny, tj. żadna próbka nie przekroczyła dopuszczalnej twardości HV (zgodnie z tabl. XI) wg PN EN ISO 15614-1:2008.

W badaniu próbki A.1 stwierdzono, że został dobrany prawidłowy materiał dodatkowy, twardości są zbliżone do wartości materiału rodzimego, jakim jest pręt. Wyniki mieszczą się w zakresie dopuszczalnej twardości, tj. maksymalnie do 380 HV. Dobrze dobrany materiał dodatkowy i wykonanie złącza zgodnie z pWPS pozwoliły osiagnać twardość spoiny nieodbiegającą znacznie od twardości prętów. Tym samym brak znacznych wahań twardości w konstrukcji prętowej nie wpłynie na jej jakość.

\section{Wnioski}

Przeprowadzenie procesu kwalifikowania technologii spawania prętów żebrowanych do zbrojenia betonu możliwe jest tylko przy jednoczesnym wykorzystaniu EN ISO 17660-1:2008 oraz EN ISO 15614-1: 2008. Korzystanie tylko $z$ jednej $z$ wymienionych norm nie daje możliwości kwalifikacji.

Zastosowana technologia wykonywania połączeń spoinami pachwinowymi prętów ze stali BSt500S elektrodami otulonymi OK 74.78 (E 552 Mn Mo B 32) zapewnia spełnienie wymagań normy PN-EN ISO 15614-1:2008.

Spawana stal BSt500S, z uwagi na korzystny skład chemiczny, ma dobre właściwości spawalnicze, a zatem można ją stosować na typowe rozwiązania konstrukcyjne węzłów spawanych przy ograniczeniu energii liniowej łuku, co zabezpiecza złącze spawane przed przegrzaniem i spadkiem właściwości wytrzymałościowych w strefie spawania.

\section{Literatura}

[1] PN-H-84023-06:1989 Stal określonego zastosowania. Stal do zbrojenia betonu - gatunki.

[2] EN ISO 17660-1:2008 Spawanie - Spawanie/ zgrzewanie stali zbrojeniowej - Część 1: Złącza spawane/zgrzewane nośne.

[3] EN ISO 17660-2:2008 Spawanie - Spawanie/zgrzewanie stali zbrojeniowej - Część 2: Złącza spawane/zgrzewane nienośne.

[4] EN ISO 15614-1: 2008 Specyfikacja i kwalifikowanie technologii spawania metali - Badania technologii spawania - Część 1: Spawanie łukowe i gazowe stali oraz spawanie łukowe niklu i stopów niklu.

[5] PN-EN ISO 17637:2011 Badania nieniszczące złączy spawanych -- Badania wizualne złączy spawanych.

[6] PN-EN ISO 5817:2009 Spawanie - Złącza spawane ze stali, niklu, tytanu i ich stopów (z wyjątkiem spawanych wiązką) - Poziomy jakości według niezgodności spawalniczych.

[7] PN-EN ISO 6520-1:2009 Spawanie i procesy pokrewne - Klasyfikacja geometrycznych niezgodności spawalniczych w metalach - Część 1: Spawanie.

[8] ISO 3452-1:2008 Non-destructive testing - Penetrant testing - Part 1: General principles.

[9] Ferenc K.: Technika spawalnicza w praktyce. Poradnik inżyniera, konstruktora i spawacza, Verlag Dashofer, 2009.

[10] Ferenc K. Ferenc J.: Konstrukcje spawane - projektowanie połączeń. WNT, Warszawa, 2000.

[11] Szubryt M.: Wymagania dotyczące spawania i odbioru konstrukcji z prętów zbrojeniowych. Przykład rozbieżności pomiędzy zaleceniami norm a praktyką. Biuletyn Instytutu spawalnictwa, $2004 \mathrm{nr} 6$, s. 51-58.

[12] Saperski Marek: Procedura kwalifikowania technologii spawania prętów żebrowanych do zbrojenia betonu. Biuletyn Instytutu Spawalnictwa, 2010 nr 1, s. 59-63.

[13] Zeman M.: Spajanie nowoczesnyh prętów żebrowanych do zbrojenia betonu w gatunku RB500W o granicy plastyczności powyżej $500 \mathrm{MPa}$. Biuletyn Instytytutu Spawalnictwa, $2004 \mathrm{nr}$ 1, s. 49-55.

[14] Zeman M.: Nowe wymagania jakościowe dotyczące spajania prętów do zbrojenia betonu. Biuletyn Instytutu Spawalnictwa, 2005 nr 1, s. 33-43. 